\title{
Hubungan kejadian laten tuberkulosis dengan kontak pada pasien tuberkulosis
}

\author{
Hadiyanto \\ Departemen Ilmu Kesehatan Masyarakat dan Ilmu Gizi, FKIK Atmajaya
}

\begin{abstract}
ABSTRAK
Laten tuberkulosis masih menjadi masalah di Indonesia, tidak adanya gejala pada pasien laten tuberkulosis membuat pasien merasa tidak memerlukan pengobatan. Banyak faktor yan g mempengaruhi seseorang menjadi laten tuberkulosis, seperti faktor dari lingkungan rumah yang lembab, kurang cahaya matahari serta ventilasi, faktor ekonomi, riwayat kontak dengan pasien tuberkulosis danfaktor imunitas. Tujuan penelitian ini untuk menganalisis hubungan k ejadian laten tuberkulosis dengan kontak pasien tuberkulosis. Penelitian ini menggunakan data peran interferon gamma sebagai biomarker efektivitas vaksin BCG. Penelitian dimulai dari bulan mei - agustus 2018, menggunakan desain penelitian potong lintang, pasien diambil di puskemas Kecamatan Tambora dan Kecamatan Penjaringan, kriteria inklusi responden yang mempunyaicatatan pemeriksaan yang lengkap yaitu pemeriksaan IGRA serta riwayat kontak dengan pasien tuberkulosis, kemudian data dianalisis dengan metoda chi squre, jumlah respoden 421 orang. Hasilpenelitian didapatkan responden wanita 265(62.9\%) orang, rentang usia responden 21 - 40 tahun berjumlah 186(44,2\%) orang, IGRA positif 123 (29,2\%) orang, responden yang memiliki riwayat kontak dengan pasien tuberkulosis 105 orang dan tidak memiliki riwayat kontak 316 orang. Prevalensi laten tuberkulosis sebesar 29 persen, prevalensi menjadi laten tuberkulosis pada responden dengan riwayat kontak sebesar 33,3 persen dan tanpa riwayatkontak 27,8 persen. Hasilanalisistidak didapatkan hubungan yang signifikan antara kejadian laten tuberkulosis dengan riwayat kontak dengan penderita tuberkulosis (p value 0,284). Oleh karena itu, perlu dilakukan penelitian lanjutan untuk memasukan varibel yang belum dimasukan di awal seperti faktor ekonomi, gizi responden, sertamelakukan pemeriksaan ulang untuk mengetahui status kesehatan terkini dari responden.
\end{abstract}

Kata kunci: laten TB; riwayat kontak; tuberkulosis

\begin{abstract}
Introduction: Latent TB is still a problem in Indonesia, the absence of symptoms in patients with latent TB makes patients feel theydon't need treatment. Aim of study: The purpose of this study was to analyze the relationship of latent TB incidence with TB contact patients. Method: This study uses research data on the role of gamma interferon as a marker of the effectiveness of the BCG vaccine, the sample in this study has a complete examination record, especially IGRA examination, then the data are analyzed by the Chi squre method. The total sample was 421 respondents. Results and Discussion: Based on the results of the study offemale respondents was 265(62.9\%), with an age range of 21-40were 186 (44.2\%) respondents, Positive IGRA 123 (29.2\%) respodents, patient contact with TB patients was 105 people, and no contact history with TB patients was 316 people. The prevalence of latent TB was 29 percent, while respondents who have a history of contact with tuberculosis patients about 33.3 percent and without a contact history of 27.8 percent. Conclusion: From the results of the analysis, there was no significant relationship between latent tuberculosis events and contact history with tuberculosis patients ( $P$ value 0.284$)$. Therefore, further researchneeds to be done to include variables that have not been included in the beginning such as economicfactors, respondent nutrition, and conduct a re-examination to determine the current health status of respondents.
\end{abstract}

Keywords: latent TB; contact history; tuberculosis

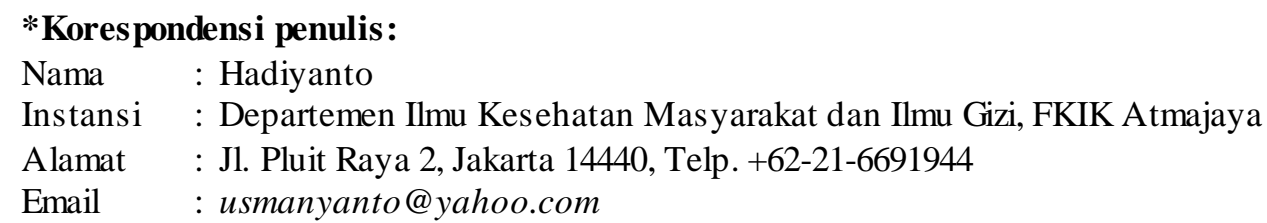




\section{Pendahuluan}

Laten tuberkulosis masih menjadi masalah di Indonesia, tidak adanya gejala atau tanda selama tidak bermanifestasi menjadi tuberkulosis aktif, $, 1,2,3,4,5$ hal ini membuat penderitanya merasa sehat dan tidak mau melakukan pemeriksaan secara dini. ${ }^{2}$ Tidak adanya angka pasti penderita laten tuberkulosis membuat pemerintah tidak dapat melakukan tindakan pencegahan secara dini, di Amerika Serikat saat ini diperkirakan terdapat sekitar 13 juta orang yang mengidap laten tuberkulosis.1 Sekitar 5 sampai 10 persen penderita laten tuberkulosis akan menjadi penderita tuberkulosis aktif jika tidak diobati. ${ }^{6,7,8}$

Banyak faktor yang memengaruhi seseorang menjadi laten tuberkulosis, seperti faktor dari lingkungan rumah yang lembab dan kurang cahaya matahari serta ventilasi, faktor ekonomi juga berperan, pada umumnya penderita tuberkulosis tinggal di daerah yang padat penduduknya serta lingkungan yang kumuh. $^{2,9}$ Faktor imunitas tubuh pasien juga berperan, pada pasien dengan imunitas yang menurun karena penyakit kronis atau infeksi seperti penyakit diabetes melitus ataupun HIV, gizi yang kurang serta kebiasaan merokok, mempunyai risiko terkena laten tuberkulosis. ${ }^{1,5,10}$

Prevalensi laten tuberkulosis yang lebih tinggi juga secara signifikan dikaitkan dengan bertambahnya usia, tingkat pendidikan, sosial ekonomi dan konsumsi alkohol. ${ }^{11}$ Beberapa studi terdahulu juga menjelaskan tentang efek merokok pada perkembangan penyakit tuberkulosis. Penelitian tersebut menjelaskan bahwa baik perokok aktif maupun pasif berisiko tinggi untuk terjadi infeksi laten tuberkulosis, progress perburukan penyakit yang relatif cepat, tingkat keberhasilan pengobatan yang lebih rendah dan kejadian kematian yang lebih tinggi. Selain itu, merokok juga telah dikaitkan dengan kavitasi yang lebih sering pada paru, beban basiler yang lebih tinggi dan risiko reaktivasi yang lebih tinggi. ${ }^{12,13}$

Merokok dapat meningkatkan kerentanan individu terhadap infeksi tuberkulosis melalui berbagai cara, salah satunya dengan berkurangnya respons IFN- $\gamma$. Perlu diketahui bahwa respons imun yang terganggu dapat memengaruhi kinerja IFN- $\gamma$ Release Assays (IGRAs). Merokok memiliki efek negatif pada tampilan klinis, penemuan radiologis dan menunda waktu konversi sputum. Hasil penelitian sebelumnya juga menjelaskan bahwa merokok memiliki hubungan yang signifikan dengan kejadian tuberkulosis karena respons IFN- $\gamma$ yang melemah disebabkan oleh asap tembakau secara langsung. ${ }^{13}$ Oleh karena itu, penelitian ini bertujuan untuk menganalisis hubungan kejadian laten tuberkulosis dengan kontak pada pasien TB di wilayah kecamatan tambora dan kecamatan penjaringan, Jakarta.

\section{Metodologi}

Penelitian ini menggunakan data sekunder, data diambil dari responden yang ikut serta dalam penelitian peran interferon gamma sebagai biomarker efektivitas vaksin BCG pada bulan September 2015-Februari 2016. Penelitian dilakukan pada bulan Mei-Agustus 2018 dengan kriteria inklusi yaitu riwayat kontak dengan pasien tuberkulosis tercatat lengkap dari hasil penelitian sebelumnya. Untuk kriteria ekslusi, yaitu data tidak tercatat lengkap, status laten tuberkulosis tidak diketahui. Per definisi operasional yang dimaksud dengan terdapat kontak dengan pasien tuberkulosis berarti responden tinggal bersama dengan penderita tuberkulosis ataupun kontak erat minimal 8 jam dalam sehari. ${ }^{14}$ Penelitian dimulai dengan melakukan pemisahan pasien terkonfirmasi tuberkulosis dahulu, kemudian memeriksa hasil pemeriksaan yang dilakukan pada semua anggota keluarga pasien baik yang positif tuberkulosis maupun yang tidak tuberkulosis, serta hasil pemeriksaan IGRA kemudian data yang ada dicatat. Untuk penentuan laten tuberkulosis dilihat dari hasil pemeriksaan IGRA positif.

Setelah data terkumpul maka dilakukan analisis menggunakan Chi Square apakah terdapat hubungan kejadian laten tuberkulosis dengan kontak dengan pasien tuberkulosis, 
dengan tingkat kemaknaan $p$-value kurang dari 0,05 .

Penelitian ini telah mendapatkan persetujuan etik dari komisi etik Fakultas Kedokteran dan Ilmu Kesehatan Atma Jaya No.14/08/KEP-FKUAJ/2018, tanggal 20 Juli 2018.

\section{Hasil dan Pembahasan}

Responden yang memenuhi kriteria inklusi dan eksklusi adalah sebanyak 421 orang, pada penelitian ini. Pada tabel 1, responden sebagian besar berada pada umur 21 sampai 40 tahun yaitu $186(44,2 \%)$ orang, dari 186 orang yang menjadi laten tuberkulosis sebanyak 71 $(38,2 \%)$ orang. Jenis kelamin terbanyak adalah perempuan $265(62,9 \%)$ orang, dari 265 orang yang menjadi laten tuberkulosis sebanyak 72 $(27,2 \%)$ orang, tingkat pendidikan sebagian besar kurang dari SD sebanyak 198 (47\%) orang, dari 198 orang menjadi laten tuberkulosis sebanyak $40(20,2 \%)$ orang. Sedangkan pada Tabel 2 didapatkan hasil pemeriksaan IGRA pada responden, hasil IGRA Positif sebanyak $123(29,2 \%)$ orang dan IGRA Negatif 298 $(70,8 \%)$ orang. Selanjutnya pada tabel 3 didapatkan bahwa tidak ada hubungan kejadian laten tuberkulosis dengan riw ayat kontak dengan pasien tuberkulosis, $P$-value 0,284 .

Tabel 1. Karakteristik Responden

\begin{tabular}{ccc}
\hline $\begin{array}{c}\text { Karakteristik } \\
\text { Responden }\end{array}$ & $\begin{array}{c}\text { Laten TB } \\
(\mathbf{n = 1 2 3})\end{array}$ & $\begin{array}{c}\text { Bukan Laten TB } \\
(\mathbf{n = 2 9 8})\end{array}$ \\
\hline $\begin{array}{c}\text { Kelompok Umur } \\
\leq 20 \text { tahun }\end{array}$ & $23(14,6 \%)$ & $135(85,4 \%)$ \\
$21-40$ tahun & $71(38,2 \%)$ & $115(61,8 \%)$ \\
$\geq 41$ tahun & $29(37,7 \%)$ & $48(62,3 \%)$ \\
Jenis Kelamin & & \\
Laki-laki & $51(32,7 \%)$ & $105(67,3 \%)$ \\
Perempuan & $72(27,2 \%)$ & $193(72,8 \%)$ \\
Tingkat Pendidikan & & \\
$\leq$ SD & $40(20,2 \%)$ & $158(79,8 \%)$ \\
SMP & $35(34,0 \%)$ & $68(68,0 \%)$ \\
SMA dst & $48(40,0 \%)$ & $72(60,0 \%)$ \\
\hline
\end{tabular}

Tabel 2. Hasil Pemeriksan IGRA Responden

\begin{tabular}{|c|c|c|}
\hline $\begin{array}{c}\text { Hasil } \\
\text { Pemeriksaan }\end{array}$ & Jumlah (n) & Percent (\%) \\
\hline Positif & 123 & 29,2 \\
\hline Negatif & 298 & 70,8 \\
\hline Total & 421 & 100,0 \\
\hline
\end{tabular}

Tabel 3. Hubungan k ejadian laten tuberkulosis dengan riwayat kontak dengan pasien tuberkulosis

\begin{tabular}{lccc}
\hline Variabel & $\begin{array}{c}\text { Laten TB } \\
(\mathbf{n = 1 2 3})\end{array}$ & $\begin{array}{c}\text { Bukan Laten } \\
\text { TB } \\
(\mathbf{n = 2 9 8})\end{array}$ & $\begin{array}{c}\boldsymbol{p}- \\
\text { value }\end{array}$ \\
\hline \multicolumn{4}{l}{ Riwayat Kontak dengan pasien tuberkulosis } \\
Ya & $35(33,3 \%)$ & $70(66,7 \%)$ & \\
Tidak & $88(27,8 \%)$ & $228(72,2 \%)$ & 0,284 \\
\hline
\end{tabular}

Penelitian ini merupakan penelitian yang menggunakan data sekunder dari penelitian sebelumnya, jumlah responden yang terdapat pada penelitian ini adalah 421 orang. Berdasarkan hasil penelitian didapatkan responden terbanyak adalah wanita, rentang usia responden adalah 21 sampai 40 tahun, dengan tingkat pendidikan adalah kurang dari SD. Responden yang terbanyak wanita disebabkan karena kaum wanita terutama ibu lebih sering berada di rumah untuk mengurusi rumah tangga dan menjaga anaknya sehingga lebih mudah menemui mereka dibandingkan dengan pria dikarenakan sibuk bekerja.

Berdasarkan dari hasil penelitian dapat disimpulkan bahwa wilayah Tambora dan Penjaringan, mempunyai penduduk yang berusia diantara 21 sampai 40 tahun yang berarti responden memiliki mobilitas yang cukup tinggi untuk sekolah ataupun mencari nafkah bagi keluarganya, pada akhirnya dapat terpapar kuman tuberkulosis dari mana saja, bisa dari saat menggunakan transportasi massal, dari teman atau rekan sekerja ataupun dari orang lain. Hal ini sesuai dengan penelitian yang dilakukan di Afrika yang mengatakan terdapat hubungan yang signifikan antara pergi ke sekolah atau bekerja dengan kejadian laten tuberkulosis. ${ }^{15}$

Pada penelitian yang dilakukan di Negara dengan tingkat perekonomian yang rendah, ditemukan prevalensi laten tuberkulosis sebesar $16,1 \%$ yang terjadi pada usia remaja berusia 12-18 tahun. Adapun faktor risiko yang memengaruhi laten tuberkulosis meliputi: usia 17-18 tahun dan 16-17 tahun, jenis kelamin lakilaki, bekas luka vaksin BCG yang terlihat, riwayat kontak dengan penderita tuberkulosis yang diketahui dalam 2 tahun terakhir dan tidak bersekolah. Negara yang memiliki tingkat 
perekonomian tinggi pada umumnya telah memasukkan anggaran kesehatan untuk pengobatan infeksi laten tuberkulosis, namun sebaliknya pada Negara yang berpenghasilan rendah biasanya lebih mengutamakan intervensi hanya untuk pasien yang terinfeksi HIV dan anak-anak yang kontak dengan penderita tuberkulosis dan kelompok berisiko laten tuberkulosis tertinggi. ${ }^{16}$

Perbedaan jenis kelamin menjadi prediktor terjadinya laten tuberkulosis. Walaupun pada karakteristik didapatkan sebagian besar responden adalah wanita, namun pada penelitian terdahulu ditemukan bahwa proporsi laten tuberkulosis secara signifikan lebih tinggi pada laki-laki daripada wanita $(\mathrm{p}=$ $0,010)$. Selain itu, perbedaan dalam proporsi laten tuberkulosis antara jenis kelamin yang paling menonjol ada pada pasien lansia. ${ }^{17}$ Wanita juga mempunyai peranan penting dalam keluarga tidak hanya mengurus keluarga tetapi juga dalam pencegahan penyakit di dalam rumah misalnya dengan membuka jendela rumah ketika membersihkan rumah, hal ini berguna agar sinar matahari dapat masuk ke dalam rumah serta membuat sirkulasi udara dalam rumah menjadi lancar, yang pada akhirnya dapat membunuh kuman penyebab tuberkulosis. ${ }^{18}$ Selain jenis kelamin laki-laki, usia, faktor lainnya yang berisiko terhadap laten tuberculosis adalah riwayat keluarga dengan penderita tuberkulosis, dan bekerja di unit pulmonologi. ${ }^{19}$

Prevalensi laten tuberkulosis pada penelitian ini adalah 29 persen, riwayat kontak pada pasien tuberkulosis yang tinggal serumah sebanyak 105 orang, dari 105 orang ini yang menjadi laten tuberkulosis sebanyak 35 (33.3\%) orang, sedangkan dari pasien yang tidak mempunyai riw ayat kontak sebanyak 316 orang, yang menjadi laten tuberkulosis sebesar 88 $(27.8 \%)$ orang. Hal ini berarti seseorang kemungkinan menjadi laten tuberkulosis setelah kontak dengan pasien tuberkulosis aktif sekitar $33.3 \%$, dan tanpa riwayat kontak dengan pasien tuberkulosis dapat menjadi laten tuberkulosis sekitar $27.84 \%$. Prevalensi laten tuberkulosis dalam penelitian ini lebih rendah dibandingkan dengan penelitian yang dilakukan di Etiophia ataupun di Afrika yaitu 63,7\% dan 49\%. Dengan prevalensi masih 29 persen berarti Indonesia masih mempunyai kesempatan yang besar untuk melakukan pencegahan dini supaya laten tuberkulosis ini tidak menjadi tuberkulosis aktif mengingat sekitar 5 sampai 10 persen dari penderita laten tuberkulosis akan menjadi penderita tuberkulosis aktif. ${ }^{1,4}$

Perlu dipahami bahwa laten tuberkulosis didefinisikan sebagai keadaan respons imun yang persisten terhadap stimulasi oleh antigen Mycobacterium tuberculosis tanpa adanya tampilan klinis tuberkulosis aktif. Individu yang laten tuberkulosis adalah reservoir untuk kasus tuberkulosis aktif. Deteksi dan pengelolaan laten tuberkulosis saat ini menjadi komponen utama dari strategi WHO dalam pengendalian dan pencegahan penyakit tuberkulosis. Hal ini penting karena individu yang laten tuberculosis dapat berkembang menjadi tuberkulosis aktif atau reaktivasi dan risiko semakin meningkat pada individu yang memiliki daya tahan tubuh yang lemah. ${ }^{20}$

Hasil uji dengan Chi Square yang menganalisis hubungan kejadian laten tuberkulosis terhadap riwayat kontak menunjukkan tidak ada hubungannya ( $p$-value $0,284)$. Dalam studi sebelumnya, kejadian laten tuberkulosis justru berkaitan erat dengan riw ayat kontak dengan penderita dimana diperolah prevalensi laten tuberkulosis yang tinggi pada individu yang pernah kontak dengan penderita sebelumnya, orang asing, tunawisma, pengguna narkoba suntik, dan tahanan negara. ${ }^{21,22}$

Untuk membuat seseorang tetap sehat harus dilihat secara holistik yang dapat dipengaruhi oleh perilaku, genetik, lingkungan, serta pelayanan kesehatan, dalam penelitian ini dapat disebabkan karena riwayat kontak dengan pasien tuberkulosis saja tidak cukup untuk membuat seorang pasien menjadi laten tuberkulosis, masih banyak faktor yang berpengaruh seperti faktor imunitas dari seseorang, faktor ekonomi, lingkungan serta gizi. ${ }^{8,9}$ Penelitian ini sejalan dengan penelitian yang dilakukan oleh Martin tahun 2008, dengan 
hasil penelitiannya riwayat kontak dengan pasien tuberkulosis tidak bermakna secara statistik ${ }^{7}$ Pada penelitian ini tidak dapat melihat faktor ekonomi, gizi dari responden serta imunitas pasien, hal ini dikarenakan tidak adanya data dari penelitian sebelumnya sehingga pada penelitian ini tidak dapat dilakukan analisa faktor-faktor tersebut yang mungkin saja berhubungan dengan kejadian laten tuberkulosis di wilayah kecamatan Tambora dan Penjaringan.

\section{Kesimpulan}

Penelitian ini membuktikan bahwa tidak didapatkan hubungan yang signifikan antara kejadian laten tuberkulosis dengan riwayat kontak dengan penderita tuberkulosis ( $p$-value 0,284). Oleh karena itu, perlu dilakukan penelitian lanjutan untuk memasukan varibel yang belum dimasukan di awal seperti faktor ekonomi, gizi responden, serta melakukan pemeriksaan ulang untuk mengetahui status kesehatan terkini dari responden.

\section{Ucapan Terima Kasih}

Litbangkes RI yang telah memberikan kesempatan untuk penelitian bersama dengan FKIK Atma Jaya.

\section{Referensi}

1. Centers for Disease Control and Prevention. Latent Tuberculosis Infection: A Guide for Primary Health Care Providers [Internet]. 2013 [cited 2020 June 9]. Available from: https://w ww.cdc.gov/tb/public ations/ltbi/def ault.htm.

2. Wijaya VN. Infeksi tuberkulosis laten diagnosis dan tatalaksana. Cdk-257 [Internet]. 2017 [cited 2020 Jun 6];44: 706709. Available from: https://fdokumen.com/document/infeksituberkulosis-laten-diagnosis-dantuberkulosis-latenantigenmycobacterium.html.

3. Ahmad S. Pathogenesis, Immunology, and Diagnosis of Latent Mycobacterium tuberculosis Infection. Clin Dev Immunol. [Internet]. 2011 [cited 2020 Jun 6];2011:1-
17.

Available

from:

https://doi.org/10.1155/2011/814943.

4. World Health Organization. Guidelines on the management of latent tuberculosis infection. Geneva: WHO; 2015.

5. Dadu A. Latent TB Infection in the WHO European Region and recommendations on LTBI's M \& E framew ork [Internet]. 2017 [cited 2020 Jun 6]. Available from: https://ww w.kncvtbc.org/uploaded/2017/06/ Session-3-

3.1_P1LTBI_in_EURAndreiDADUeng-3105-final.pdf.

6. Centers for Disease Control and Prevention. TB Elimination Tuberculosis: General Information [Internet]. 2011 [cited 2020 Jun 6]. Available from: https://www.cdc.gov/tb/publications/factshe ets/general/tb.pdf.

7. Martin U, Hasibuan P. Prevalens TB Laten Pada Petugas Kesehatan Di RSUP H. Adam Malik Medan. J Respirasi Indones. [Internet]. 2010 [cited 2020 Jun 6];30(2):112-18. Available from: http://arsip.jurnalrespirologi.org/wpcontent/uploads/2012/04/112-8-APRILVOL_30-NO_2-2010-5.pdf

8. Reviono R. Pedoman Tatalaksana Infeksi Tuberkulosis Laten Dari PDPI. Surakarta [Internet]. 2017 [cited 2020 June 9]. Available from: http://spesialis 1.pikr.fk.unair.ac.id/wpcontent/uploads/2017/05/PEDOMANINFEKSI-TUBERKULOSIS-LATENDARI-PDPI-Dr.Reviono.pdf.

9. Kementerian Kesehatan Republik Indonesia. Pedoman Nasional Pengendalian Tuberkulosis [Internet]. Kementrian Kesehatan Republik Indonesia: Jakarta; 2011 [cited 2020 June 9]. Available from: http://rspauhardjo.ddns.net:8080/perpustaka an/property/uploads/d8c81b3affec9ce9d840 d2a53d26475a.pdf.

10. Esmail H, Barry CE 3rd, Young DB, Wilkinson RJ. The ongoing challenge of latent tuberculosis. Philos Trans R Soc Lond B Biol Sci. [Internet]. 2014 May 12 [cited 
2020 June 9];369(1645):20130437.

Available from: https://doi.org/10.1098/rstb.2013.0437.

11. Yap P, Tan KHX, Lim WY, Barkham T, Tan LWL, Chen MI-C, et al. Prevalence of and risk factors associated with latent tuberculosis in Singapore: A cross-sectional survey. International Journal of Infectious Diseases [Internet]. 2018 [cited 2020 June 9];72:55-62. Available from: https://doi.org/10.1016/j.ijid.2018.05.004.

12. Duarte R, Lönnroth K, Carvalho C, Lima F, Carvalho ACC, Muñoz-Torrico $\mathrm{M}$, et al. Tuberculosis, social determinants and comorbidities (including HIV). Pulmonology [Internet]. 2018 [cited 2020 June 9];24(2):115-119. Available from: https://doi.org/10.1016/j.rppnen.2017.11.00 3.

13. Altet N, Latorre I, Jiménez-Fuentes MÁ, Maldonado J, Molina I, González-Díaz Y, et al. Assessment of the influence of direct tobacco smoke on infection and active TB management. PLoS One [Internet]. 2017 Aug 24 [cited 2020 Jun 6];12(8):e0182998. Available

from: https://doi.org/10.1371/journal.pone.018299 8.

14. Pedoman Penyehatan Udara Dalam Ruang Rumah. Peraturan Menteri Kesehatan Republik Indonesia Nomor 1077/MENKES/PER/V/2011 [Internet]. 2019 Okt [cited 2020 June 3]. Available from:

http://hukor.kemkes.go.id/uploads/produk_h ukum/PMK\%20No.\%201077\%20ttg\%20Pe doman\%20Penyehatan\%20Udara\%20Dalam \%20Ruang\%20Rumah.pdf.

15. Kizza FN, List J, Nkwata AK, Okwera A, Ezeamama AE, Whalen $\mathrm{CC}$, et al. Prevalence of latent tuberculosis infection and associated risk factors in an urban African setting. BMC Infect Dis. [Internet]. 2015 Mar 29 [cited 2020 June 3];15:165. Available from: https://doi.org/10.1186/s12879-015-0904-1. 16. Mumpe-Mwanja D, Verver S, Yeka A,
Etwom A, Waako J, Ssengooba W, et al. Prevalence and risk factors of latent Tuberculosis among adolescents in rural Eastern Uganda. Afr Health Sci. [Internet]. 2015 Sep [cited 2020 June 3];15(3):851-60. Available from: https://doi.org/10.4314/ahs.v15i3.20.

17. Ting WY, Huang SF, Lee MC, Lin YY, Lee $\mathrm{YC}$, et al. Gender disparities in latent tuberculosis infection in high-risk individuals: a cross-sectional study. PLoS One [Internet]. 2014 Nov 4 [cited 2020 June 3];9(11):e110104. Available from: https://doi.org/10.1371/journal.pone.011010 4.

18. Sumarmi S, Duarsa ABS. Analisis Hubungan Kondisi Fisik Rumah Dengan Kejadian TB Paru BTA Positif di Puskesmas Kota Bumi II, Bukit Kemuning dan Ulak Rengas Kab. Lampung Utara Tahun. J Kedokt Yars [Internet]. 2014 [cited 2020 June 3];22(2):82-101. Available from: https://media.neliti.com/media/publications/ 104352-ID-analisis-hubungan-kondisi-fisikrumah-de.pdf.

19. Sabri A, Quistrebert J, Naji Amrani H, Abid A, Zegmout A, Abderrhamani Ghorfi I, et al. Prevalence and risk factors for latent tuberculosis infection among healthcare workers in Morocco. PLoS One [Internet]. 2019 Aug 15 [cited 2020 June 3];14(8):e0221081. Available from: https://doi.org/10.1371/journal.pone.022108 1.

20. Kiazyk S, Ball TB. Latent tuberculosis infection: An overview. Can Commun Dis Rep. [Internet]. 2017 Mar 2 [cited 2020 June 3];43(3-4):62-66. Available from: https://doi.org/ 10.14745/ccdr.v43i34a01.

21. Lee SJ, Lee SH, Kim YE, Cho YJ, Jeong YY, Kim HC, et al. Risk factors for latent tuberculosis infection in close contacts of active tuberculosis patients in South Korea: a prospective cohort study. BMC Infect Dis. [Internet]. 2014 Nov 18 [cited 2020 June 3];14:566. Available from: https://doi.org/10.1186/s12879-014-0566-4. 
CoMPHI Journal: Community Medicine and Public Health of Indonesia Journal

Vol. 1, No. 1, Juni 2020, hlm. 44-50

22. Horsburgh CR, Jr, Rubin EJ. Clinical practice. Latent tuberculosis infection in the United States. N Engl J Med. [Internet]. 2011 [cited 2020 June 3];364(15):14411448. Available from: https://doi.org/10.1056/NEJMcp1005750. 